\title{
Digging our own grave: A Marxian consideration of formal education as a destructive enterprise
}

\author{
Alan Bainbridge ${ }^{1}(0)$ \\ Published online: 17 October 2020 \\ () UNESCO Institute for Lifelong Learning and Springer Nature B.V. 2020
}

\begin{abstract}
The negative impact of human activity has been known throughout history. The epic tale of Gilgamesh, Koranic and biblical texts all make clear the potential that humans have to destroy the world in which they live. Climate breakdown, biodiversity collapse and zoonotic diseases such as COVID-19 have also been predicted well in advance. The "wicked problem" (dilemma) to address is: "Why do humans still persist in 'digging their own graves' by damaging the environments they inhabit?" The author of this article argues that the motive to engage in education can be understood as an ancient human response to ecological change. This has led to a range of behaviours, including teaching and learning that serve only to further disrupt the relationship between the human and the "more-than-human" world. When formal education structures are viewed through a Marxian lens, it soon becomes clear that the unsustainable impact of humans on the more-than-human is the result of capitalist entrapment. Karl Marx's proposition of a metabolic rift helps make sense of the nonsensical, while a discussion of use and exchange value shows how formal education has become ensnared in the mire of capitalist productivity, concealing from view the educationally-induced destruction of planetary systems that support human flourishing. Fortunately, a more sustainable and sustaining education is possible this is an education for a "long-life" that is no longer influenced by the machinery of neoliberalism.
\end{abstract}

Keywords capitalism $\cdot$ metabolic rift $\cdot$ adaptive lag $\cdot$ ecology $\cdot$ sustainable education $\cdot$ COVID-19 $\cdot$ open world $\cdot$ closed world

\section{Résumé}

Nous creusons notre propre tombe : une réflexion marxiste sur l'éducation formelle considérée comme une entreprise destructrice - L'impact négatif de l'humanité a été constaté à travers l'histoire tout entière. L'épopée de Gilgamesh ou encore les textes

Alan Bainbridge

alan.bainbridge@canterbury.ac.uk

1 Faculty of Arts, Humanities and Education, Canterbury Christ Church University, Canterbury, UK 
du Coran et de la Bible révèlent la propension de l'homme à détruire le monde dans lequel il vit. Le dérèglement climatique, l'effondrement de la biodiversité et les zoonoses comme la COVID-19 avait été prédits depuis bien longtemps. Le dilemme qui se pose quand on aborde cette question : « Pourquoi les hommes persistent-ils à 'creuser leur propre tombe' en portant atteinte à leur propre environnement ? » L'auteur de cet article affirme que l'on voit dans la raison qui pousse à s'instruire une réponse humaine historique au changement écologique, ce qui a entraîné l'apparition de tout un ensemble de comportements, y compris l'enseignement et l'apprentissage qui servent juste à perturber encore plus les rapports entre le monde humain et le monde « au-delà de l'humain ». En observant les structures de l'éducation formelle à travers le prisme marxiste, on s'aperçoit rapidement que l'impact préjudiciable des humains sur le monde au-delà de l'humain est le résultat d'un piégeage capitaliste. La notion de rupture métabolique proposée par Karl Marx aide à comprendre cette absurdité, tandis qu'un débat sur la valeur d'usage et d'échange illustre comment l'éducation a été pris au piège du bourbier de la productivité capitaliste, dissimulant la destruction, induite par l'éducation, des systèmes planétaires qui soutiennent l'épanouissement de l'être humain. Heureusement, une éducation plus durable et plus nourrissante est possible - une éducation pour une « longue vie » qui ne serait plus influencée par les rouages du néolibéralisme.

\section{Introduction}

Despite the ravages of a global pandemic, my day has started in comfort and convenience thanks to the political and technological achievements of the human species. I have emerged rested from a safe, comfortable night's sleep, made tea with clean water, fed the cat, bought fresh bread, and sat down to finish writing this piece supported by reliable electricity and internet services. Children are returning to school as universities plan for the next academic year. ${ }^{1}$ In this article, I wish to disrupt assumptions of human triumph over adversity by echoing philosopher Tim Morton's (2013) suggestion that the end of the world has already happened. I will then take a further provocative step to acknowledge the "wicked problem" that formal education ${ }^{3}$ is complicit in this destruction.

Ancient and religious texts provide a long-life view of human-instigated ecological destruction. Gilgamesh, in his quest for fame, destroys the cedar-forested home of the gods. In Christian mythology, Eve's desire to eat the apple and have the

\footnotetext{
1 This article was drafted in July 2020.

2 A wicked problem is a social issue which is difficult or impossible to fix because of the different rights and perspectives of all the interested parties involved.

3 Formal education or learning happens in schools and other educational institutions, and is documented by certificates. It is one of the three types of learning that comprise lifelong learning. The other two types are non-formal learning, which occurs outside the formal system, but is still intentional (e.g. learning a language in a community learning centre) and informal learning, which is often accidental and occurs at home, at work, or during a leisure activity.(e.g. learning to identify edible plants or how to bake a cake).
} 
knowledge of a god leads to the ground being cursed and the "Fall of Man" (sic). In the Qur'an, Adam and Eve are admonished for eating the fruit, but guided out of the "garden" to encourage others to be good guardians of God's creation. The Bhagavad Gita identifies the tension between the purity of the biotic and abiotic world ${ }^{4}$ and the negative impact of human activity. In this article, I argue that the global coronavirus pandemic currently causing widespread personal grief and catastrophic damage to economic, social and educational systems constitutes yet another example of the negative environmental impact of human actions, particularly those motivated by capitalist assumptions. The educational question that requires our attention is a comparatively simple one: "Why do humans continue to damage themselves and the planet on which they depend, and why do they not learn from their mistakes?"

To go some way towards answering this question and providing a hopeful way out of this dilemma, I draw on an understanding of human learning that is rooted in an ecological need to construct and manage the external world. This leads to the alienation of humans from the natural, more-than-human world. I use Karl Marx's discussion of how capitalist activities led to the Industrial Revolution, including the ideas of historical materialism and metabolic rift, ${ }^{5}$ to show how humans have become increasingly alienated from their own labour and relationship with the natural world. This analysis positions capitalist-informed neoliberal human activity, including formal education, as complicit in the current COVID-19 crisis. Finally, even though I accept that humans will continue to dig their own graves, I show that education can be a place for hope and a better future.

Before continuing, it is worth noting that this article takes a decidedly English perspective, reflecting my limited world-view, trapped as I am within my own dialectic context. Any other position would potentially be guilty of awkward and insensitive appropriation of cultures of which I have little knowledge. I can confess to an unease referring above to sacred texts, of most of which I have little, if any, lived experience. Nevertheless, what ecological and Marxian ideas do offer is a reasonable attempt to provide critical analysis of human activity, such as formal education, and to suggest radical alternatives. The global impact of neoliberalism and the universality of ecological principles give me confidence that the themes I identify here will resonate across a wide variety of social and cultural worlds, despite my own Anglo-centrism.

\footnotetext{
${ }^{4}$ Biotic refers to living organisms; abiotic refers to "lifeless" items.

5 These concepts are discussed in more detail later in the article. For now, in a nutshell, historical materialism refers to the study of the material conditions that influence the development of human society, and metabolic rift refers to the alienation of humans from nature and the depletion of natural resources as a result of industrial practices.
} 


\section{Adaptive lag and ecol-agogy}

In this section, I consider education as an evolutionarily expensive process involving teachers and learners, distinguishing it from broader human learning. I argue that the origins of human learning are located within particular environmental niches and that, unlike most other animals (Bainbridge 2019), humans engage in activities that have unintended negative consequences for the environment, and hence for human flourishing. The impact of human activity over the millennia has led to increased alienation between the human and more-than-human natural worlds (Laland and Brown 2006). A vicious circle then ensues in which this alienation motivates the development of formal educational environments, which, paradoxically, lead to further alienation. The discussion presented here offers an archaeological exploration of the human mind (Lent 2017), and as such can only be hypothetical. Yet I argue that this perspective goes some way towards explaining the "wicked problem" of continual negative human impact on the environment, including the coronavirus pandemic, and shows why formal education is part of this problem.

Drawing on the work of Peter L. Berger and Thomas Luckmann (1966), a distinction can be made between learning experiences in an "open" or "closed" world. Elsewhere, (Bainbridge 2019, 2021; Bainbridge and Del Negro 2020), I have explored in more detail how open-world experiences may have led to the development of formal education settings, formulating an ecol-agogical ${ }^{6}$ hypothesis of human learning. For reasons that may never be known, particular environmental changes in the distant evolutionary past threatened early hominid survival, leading to what Berger and Luckmann (1966) refer to as an "open-world" experience. It is in this context that humans, in order to survive, began to engage in niche construction activities that would ultimately impact negatively on themselves and their environment. To understand this paradoxical situation, it helps to consider the "closed-world" experience first, representing, as it does, how most animals live their lives.

Animals born into "closed worlds" (Berger and Luckmann 1966) are ready to be active and thrive in their environments. For example, the European badger (Meles meles) is born ready to live a badger life. These animals do not need to change or modify their world beyond the usual minor adjustments required by gradual environmental change. In biological language we would describe these animals as being adapted to their particular niche. In Berger and Luckmann's terms, they are "coupled" with their external world. Badger actions are part of a complex self-adjusting ecology that supports badgers and all other species associated with them. Importantly, their actions do not harm their niche or supporting ecology. This is not true of life in an open world.

Due to selective evolutionary pressures, possibly linked to availability of food (Kendal 2011; Tomasello 2008), the world our ancient human ancestors experienced could not directly support them. Species survival therefore required active attempts

\footnotetext{
${ }^{6}$ In a nutshell, the term "ecol-agogy", combining ecology and pedagogy, explains the development of human teaching and learning behaviours from an evolutionary perspective. The concept is discussed in more detail later in this article.
} 
to modify the external "open" world, for example by the development of agriculture (Tomasello 2008). Berger's (1967) discussion of human world construction provides further insight into why, unlike in the "closed-world" experience, humans continually modify and damage their external world. Berger argues that human products (physical and psychological) have an internal logic whereby their properties are in conflict with the properties of the external world, and thus (ironically) disrupt human flourishing. Berger uses the example of the plough. Although designed by humans to make the job of cultivation easier, in the long term, Berger argues, the plough disrupts agricultural lifestyles and soil ecology as human activity now conforms to the logic of the plough and ploughing. Equally, the global coronavirus pandemic, although entirely predictable, will be shown in the next section to result from the unintended consequences of human activity. Unlike the dynamic in closed worlds, the process of learning about and interacting with the external world continues to disrupt, requiring contextual life-long and evolutionary long-life learning (Vujaković 2013).

For most animals, learning takes place either via simple stimulus/response actions or, for more advanced behaviours, by imitation. Humans, by contrast, continually modify the world they live in, requiring creative and novel responses. Kevin Laland and Gillian Brown (2006) have shown through mathematical modelling how the impact of human learning responses to modify the environment has led to an ever-increasing gap between the rates of genetic and cultural evolution. They refer to this as the "adaptive-lag" hypothesis, positing the human cultural experience as becoming ever further removed from both genetic make-up and existing environmental conditions. Adaptive lag (a delay in adjusting to new conditions) is not experienced within a typical co-evolved closed world, as the pace of environmental and genetic change over time are in sequence and similar.

The ecol-agogical hypothesis (Bainbridge 2019) argues that humans' tendency to learn about, act on and be educated about their world is a response to the openworld experience of adaptive lag. Early in human evolution, familial informal learning would have been sufficient to support most aspects of human life. Over time, as the adaptive lag increased, this response was no longer sufficient to meet the urgent demands of living in increasingly complex cultural and technological worlds. Behaviours therefore evolved where care, support and nurturing began to extend outside the family, ultimately leading to the evolutionarily expensive process of formal education. Here, valuable resources are diverted to support the role of teachers and create discrete places of learning (kindergartens, schools, universities, etc.) where knowledge and skills are passed on to help the next generation imagine and build a better future.

Unfortunately, in this attempt to ameliorate the adaptive-lag experience, as with the plough, the internal logic of the physical and psychological products resulting from formal education has only served to further alienate humans from their increasingly complex external world. One result is an exponential educational "arms race"7

\footnotetext{
7 An arms race is a potentially never-ending competition (usually between nations) to have the most and the best weapons.
} 
reflected in the never-ending development of the role of the teacher, pedagogical approaches, and the influence of formal education across the lifespan, to the extent that (in England at least) young children start school when they are just four years old and are expected to stay until they are eighteen. At that point, almost 50 per cent of school leavers continue into higher education, while 2.2 million students (AoC 2020) are in post-compulsory education or what is referred to in the United Kingdom (UK) as further education (FE). ${ }^{8}$ Those in employment also enter a world of continuous professional development. Ecol-agogical long-life learning assumptions suggest that the outcomes of formal education will never be sufficient, as these activities only serve to increase adaptive lag. Seen in this light, the idea of formal education appears endless; even remorseless.

A way out of this potential educational life sentence is to consider education as a more expansive long-life process, as opposed to one that is life-long and defined by compulsion, developmental stages, testing and a continuous search for excellence. Hypothesising very early human experience has provided a different, perhaps radical lens through which to view education. The next section further develops the idea that contemporary formal education has the unintended consequence of disrupting human functioning, alienating the learner not only from the natural world, but also from a potentially more positive form of human learning. The work of Marx is used to suggest how, despite formal education's best intentions, humans continue to damage themselves and their planet, and fail to learn from their mistakes.

\section{Historical materialism: estrangement}

The work of Karl Marx exposes how the rise of capitalism further estranged humans from nature, and how this relates to the commodification of education and the potential to alienate learners from learning. I begin by outlining Marx's ideas of commodification and what has later been termed metabolic rift (Foster 1999) before applying them to education and learning.

Writing at the time of the English Industrial Revolution, Marx drew heavily on the detailed accounts recorded by factory inspectors and on his close working relationship with Friedrich Engels, himself a factory owner. Marx's writings provide one of the most comprehensive accounts of the interaction between social, ecological and economic factors and industrial working life. His theory of historical materialism describes metabolism as the "human relation to nature through labour" (Foster 1999, p. 380). In Capital, Marx (1996 [1887]) makes it clear in the chapter on "Machinery and Large-Scale Industry" that humans and nature are in a dialectic relationship: just as humans influence and change the environment, so environmental changes influence human functioning. Marx notes how this dialectic has led to entrapment by the assumptions and processes of capital, eventually alienating the worker from their means of production (and, I would argue, the learner from learning).

\footnotetext{
${ }^{8}$ Further education refers to practice-oriented secondary-level education such as work-based learning and apprenticeships.
} 
Marx makes a comparison between the labour activity of spiders and bees and that of humans (ibid., p. 27). What distinguishes these two different types of labour is that spiders and bees, although their constructions are indeed impressive, always produce similar webs or honeycomb cells. Human construction, on the other hand, is always preceded by an idea or fantasy of what something could be like. Human creativity is thus continually evolving. The dialectic "rules" of historical materialism suggest that human constructions will have emerged from a particular context or environment to produce something new, and that these constructions now in turn determine future modes of human activity. In the context of the Industrial Revolution, more and more impressive technological advances led to the logic of machinery changing working practices and alienating workers from the products of their labour. Moreover, as women and children now also worked in factories, these developments provoked profound changes in how family life was organised. There are clear parallels here with Berger and Luckmann's (1966) account of open-world experiences. An exploration of Marx's work offers an insight into the paradoxical way in which humans may become entrapped by the internal logic of their own typically well-meaning constructions.

I have already noted how ancient humans, in their attempt to make environments more suitable for human flourishing, initiated an ever-increasing adaptive lag. Marx also identifies a "gap" in the human/nature dialectic relationship, not in the ancient past, but as the outcome of capitalism during the Industrial Revolution. Marx identified the problem of soil degradation and depletion of essential minerals due to the industrialisation of agriculture and the globalisation of markets (Marx 1996 [1887], p. 329). John Bellamy Foster provides the term "metabolic rift" in relation to soil depletion, citing Marx's description of an "irreparable rift in the interdependent process of the social metabolism, a metabolism prescribed by the natural laws of life itself" (Foster 1999, p. 79).

One of the outcomes of the Industrial Revolution was that workers no longer produced within the "natural laws of life itself" but were now shackled to the efficiency of machines. The working day was made longer and reorganised on the basis of shift patterns that supported profit-motivated continuous production. Unlike machines, however, human workers can only work within human(e) limits. Indeed, the purpose of the detailed factory inspector reports produced at the time was to ensure worker safety.

The coronavirus pandemic can also be explained largely as an example of capitalist-induced metabolic rift. David Harvey (2020) argues that pandemics can be traced back to profit-motivated human interference in the ecosystem which allows zoonotic pathogens ${ }^{9}$ such as the SARS-CoV-2 virus to enter the human food chain, either through extensive deforestation or the increasing need for the poor to seek out other food sources such as those found in "wet markets". ${ }^{10}$ Central to these examples of metabolic rift is the principle of finite resources being used in a process of

\footnotetext{
9 The adjective zoonotic characterises a disease as being spreadable from animals to humans; pathogens are bacteria, viruses, or other microorganisms which can cause diseases.

10 A wet market (found mainly in China and Southeast Asia) offers fresh meat and fish for sale.
} 
continual construction or modification of external worlds. Marx's prediction (Marx 1996 [1887], p. 329) that industrialisation would deplete the planet's finite mineral resources moves towards considering the "wicked problem" of why humans continue to damage the planet that supports them.

Just as Berger and Luckmann (1966) acknowledge the dialectic possibility of human-made machines determining how workers work, Marx's analysis (1996 [1887], p. 27) identifies how the principles of capitalism lead to such entrapment. The commodity is the fundamental form within the capitalist model and represents both what is available (what can be bought and sold) and what may be hidden by this process. Essential to Marx's radical thinking was the discovery of different types of value and how these hide the negative impact of metabolic rift.

Marx termed the value of a product for its actual material essence "use value". The value of the same product when converted into money in a market economy is referred to as its "exchange value". Significantly, the capitalist's motivation is to accumulate relative surplus value, or profit. Marx also identified the "magic trick" (1996 [1887], pp. 47 and 50) of fetishised commodities, where competition leads capitalists to focus on exchange value and the accumulation of wealth in the form of monetary profit. In this case, the use value of a commodity is hidden by the exchange value. To purchase a commodity, individuals are then prepared to exchange an amount of money which exceeds that commodity's use value. For example, the monetary exchange value of a fashionable pair of trainers (sports shoes) might far exceed the actual use value of the materials and cost of production. This is the "magic trick" of Marx's commodity fetish, where the consumer has been seduced into paying an exchange value which exceeds the use value of commodity they are purchasing, thus enhancing the profit margins of a distant and unknown individual or organisation.

These ideas - Marx's radical understanding of capitalist entrapment through metabolic rift, the fetishisation of commodities, and the distinction between use and exchange value - can also help us understand formal education settings. Just as the coronavirus pandemic can be seen as the outcome of capitalist incursions into a fragile ecology, the next section below exposes how education policy and process have come under the spell of the capitalist fetishised accumulation of wealth, thus estranging the learner from learning while exacerbating the destructive impact of humans on the more-than-human world. This section takes another step towards addressing the "wicked problem": "Why do humans continue to dig their own grave?"

\section{Commodification of education: estrangement of the learner}

That education has become a commodity is not a particularly new idea. Ivan Illich (1971), Stephen Ball (2018) and myself and my colleagues (Bainbridge et al. 2018) have all made similar claims. As a Marxian dialectic approach ${ }^{11}$ would predict, the

\footnotetext{
11 Marxian dialectic refers to how the material world is reflected in the human mind as ideas, leading, in turn, to the construction of materials.
} 
influence of commodification on thinking has, in turn, had considerable influence on educational systems around the world. This article now moves on not only to highlight how capitalist market-driven principles alienate the learner from learning, but also to provide an alternative view that seeks to reject marketised neoliberal incursions into education policy. Using Marx's own metaphor, this article seeks to expose capitalism's magic trick that hides use value behind exchange value and accumulation of resources (for more details on "magic tricks" in higher education, see Bainbridge et al. 2018).

From my English perspective, the commodification of education throughout the lifespan now seems complete. Education settings are dominated by neoliberal accountancy technologies, including the regular surveillance of learners and teachers to inform local, national and even international league tables. Management hierarchies focused on monitoring and control dominate all sectors, along with excessive salaries for managers that in many UK schools and universities exceed that of the Prime Minister. England has a particularly pernicious (harmful) fee-paying school system where education and social advantage can literally be purchased. Sol Gamsu and Michael Donnelly (2020) show how the route to elite university study is through a small number of influential (mainly fee-paying) schools. The earning potential of graduates is now measured, reported and compared in the absurdly inappropriate "Teaching Excellence Framework". ${ }^{12}$ A recent report (Jerrim 2017) found that an estimated GBP 2 billion is spent each year in private tuition for 11-16-year-olds. Many of these developments are lauded in the belief that they encourage accountability and raise standards. I argue that this is in fact the outcome of capitalism's magic trick whereby commodities, including education, are bought and sold without any thought of the violent and hidden consequences of the metabolic rift they have created.

Marx originally argued that the estrangement of workers from the products of their labour and the degradation of soil by industrial agricultural techniques represent a metabolic rift caused by the fetishised conflation of the use and exchange value of commodities. From this perspective it is helpful to look underneath the surface and to question narratives of educational "standards", "accountability" and even "learner-centredness". Just as Marx showed that workers no longer had control of either their working life or the products of their labour, I argue that despite neoliberal protestations to the contrary, the learner is being cast aside from their own learning experience.

Learners are now swept up in a maelstrom of national standards, targets and rates of age-expected progress (Burgess 2020). As I write this (in July 2020), English schools in COVID-19 "lockdown", until recently only accepting the children

\footnotetext{
12 The Teaching Excellence Framework (TEF) is a system that attempts to assess "the quality of teaching in universities in England. It also includes some universities from Scotland and Wales. The framework was introduced by the government in 2017 to provide a resource for students to judge teaching quality in universities and to increase the importance of teaching excellence (and bring it into line with research excellence) when rating institutions" (Bhardwa 2019).
} 
of "key" or "essential workers", ${ }^{13}$ have just begun to re-admit more of their pupils. While hundreds of people are still dying every day and the contagion rate of the virus remains high in England (close to R1), ${ }^{14}$ it is argued that delaying the return to school could damage children's "progress". While acknowledging that children benefit from attending school, such seemingly premature re-admissions overlook the possibility that many children may be learning outside of school (albeit perhaps in a way that is not so easily measured and reported). This nationally managed approach to individual learning is facilitated by a suite of inflexible (even in the context of COVID-19), highly structured curricula and testing regimes that span from ages 4 to at least 18. William Rowlandson (2020) refers to this as a pedagogical monoculture masquerading as education, where individuals are swamped by principles of accountability rather than of learning. Arguably, these approaches are of more benefit to the managers and organisations squabbling for status in the highly-publicised league tables than they are to the students themselves.

Finally, in a manner reminiscent of the industrial capitalist's drive to maximise profit through the greater efficiency provided by continual technological change, the English education system has experienced a unique period of relentless reform as successive governments and ministers seek to improve on previous structures and processes. Significantly, the influence of policymakers has entered previously uncolonised territory, with audit principles now demanding the baseline testing and reporting of 4-year-olds, as well as the monitoring of graduate income, and the destruction of adult education deemed too expensive (Bainbridge and West 2020). Not only are formal education settings increasingly heavily monitored and reported; their influence across the lifespan has also risen. The expansion of formal education, now compulsory until the age of 18 in England, reflects the factory owner's extension of the working day and the expectation that workers should work for as much of their lifespan as possible.

Marx asked difficult questions about this situation, and they are no less relevant today. Whom does it really benefit? Does this level of control and accountability benefit learners, the organisations and managers supporting them, or a succession of government ministers? The violence exposed in this article is twofold: it refers both to the conflation of educational use and exchange value alienating the learner from learning, and to the concealment of the consequences of human actions, such as plundering the planet's finite forestry resources and exposing the population to the lethal SARS-CoV-2 virus. The next section enters this territory and seeks to look under the surface of the metabolic rift to investigate what has been hidden and lost in capitalism's magic trick.

\footnotetext{
13 Key or essential workers are employed in jobs which are necessary to keep daily life going. Besides health care staff, police officers, fire fighters and utilities staff, they include supermarket employees, public transport drivers etc.

14 In the context of measuring the spread of infectious diseases, $R$ is the reproduction number, and $R I$ means that one infected person on average infects one other person they come into contact with.
} 


\section{Education's entrapment and magic tricks}

Education's response to COVID-19 exposes what has been hidden and lost from human learning in the relentless move towards an increasingly monitored formal education system. Recognising the conflation of formal education with individual human learning goes some way towards exposing the contrasting and conflicting epistemologies of learning and capital. I will draw on Gert Biesta's conception of "learnification" (Biesta 2013), ${ }^{15}$ which offers an inclusive and global consideration of what it may mean for humans to learn. Biesta provides three domains of educational purpose: qualification (the main knowledge transfer focus of schooling); socialisation (being inducted into the social world); and subjectification (where the individual becomes a subject and can make purposeful responses). For Biesta, this final and crucial domain has largely been ignored, particularly during the recent neoliberal incursion into education. For Biesta, the purpose of "good" education is to enable "subjectified" individuals to make decisions based on knowledge and social context that can support the flourishing of the self, the other, and the planet we live on. I contend that subjectification is the dimension of learning that has been hidden and lost in the entrapment of capital's magic trick.

I argued above that the commodification of formal education has resulted in use value becoming obscured by exchange value due to the capitalist quest for everincreasing profit gains. I now wish to argue that the use value of human learning within formal education is to be found in subjectification, and not in the accumulation of qualifications, certificates, awards, league table positions, or future earnings. It is in subjectification that individuals become knowledgeable subjects situated in their particular social context, and are therefore more likely to make decisions leading to positive outcomes for themselves, others and the planet. I do not claim that exchange value aspects of education have no merit, but I believe that they have become so dominant and fetishised that other, more human aspects of education are being lost from individual, institutional and even national memory.

At a recent meeting of politically active educationalists, I offered up an ideal vision of education to campaign for, but was dismissed as being fanciful and not knowing what parents wanted. I had in fact described my own experience as a young teacher almost forty years ago. My activist colleagues had apparently either forgotten or never encountered the possibility of schools and teachers working collaboratively and sharing resources and ideas. Of local authority-funded Reading and Teacher Centres, educational psychologists, speech therapists, orchestras, sailing clubs and mountain centres they had no notion. My spirit sinks as I type: what have we lost? Particularly as the response of education settings to COVID-19 would have been so much more effective if these systems were still in place. This was not a perfect education - adaptive lag and capitalist entrapment saw to that - but it was

\footnotetext{
15 What Biesta means by learnification is "the redefinition of all things educational in terms of learning - such as calling students learners, calling schools learning environments or places for learning, referring to adult education as lifelong learning, and seeing teachers as facilitators of learning" (Biesta 2019, p. 549).
} 
nevertheless an education that sought to empower the child, community and teaching professionals, irrespective of test scores and league tables.

In a world where the punitive eye of neoliberal accountability is ever-present, such a stance is risky for teachers, learners and parents, and is therefore largely avoided. Educational language and policy at local, national and international levels hide this fundamental use value aspect of human learning and subsume it beneath exchange value factors such as qualification, attendance rates, reading "gains" and future earning capacity. The current focus in England under COVID-19 lockdown (Burgess 2020) is on enabling children to return to school to "make up lost attainment", highlighting the focus on bizarre notions of time-limited development assured and measured by "qualification". This is not to suggest that socialisation factors have been ignored; indeed, these have often been raised as a vital aspect of education curtailed by lockdown. Arguments about education's role in subjectification, however, have been entirely absent from the discussion. The Marxian magic trick of commodification would suggest that this aspect of education has been hidden by the focus on exchange value and the accumulation of educational "wealth".

COVID-19 has not brought about these distinctions. Rather, it has exposed weaknesses and deceit already inherent within the education system. In Bainbridge et al. (2018) we make the provocative claim that neoliberal practices have begun to bring about the death of human learning, tamed and controlled as it is by external managers and policymakers. Rather than deal with the difficult-to-measure use value of "subjectified" learning, education has been sanitised into a series of exchange value measures. Across the education spectrum, testing, reporting, adherence to frameworks, and public celebration or humiliation have eclipsed the dynamic of what might happen between learners, teachers and social settings. Just as the products of the artisan worker have been removed from their control, so too have the "products" of the artisan learner. The process and outcome of human learning have been seized upon, controlled by an educational technology, converted into auditable fragments of knowledge or skills and stripped of their individual meaning. The measurable outcomes of individual learners are now offered up in league tables where the market determines the "winners": teachers, schools, or countries deemed "excellent" and therefore, on the back of the academic labour of others, likely to receive higher salaries and greater investment. In England, the equation is a simple one and it obliterates human learning as a means of caring for the self, others and the planet. High individual scores (productivity) $=$ high league table position $=$ increased and more selective pupil/student intake $=$ increased income $=$ domination of the "market".

The desire, declared or not, to dominate and accumulate more educational wealth is analogous to the capitalist drive for increased profit margins at the expense of the worker's pay, working conditions and family life. The Industrial Revolution led to a dramatic increase in technological innovation as each factory owner sought to be more efficient and profitable than their competitors. Likewise, in contemporary education teachers and lecturers compete against each other in the hope of finding new schemes or models to make their learners more "successful", whilst educational 
institutions search for their "unique selling point"16 and governments continually tamper with policy in the hope of scoring more highly in global league tables and fuelling economic growth. Caught up in this are greedy publishers, software companies and media outlets all vying to enter a market where their innovative "golden bullet" $" 17$ will improve qualified outcome, at the expense of more subtle and nuanced aspects of human learning (Bainbridge 2014).

Finally, to confirm the propensity of the market to destroy the use value of education and encourage educationalists to dig their own graves, the complex and tentative nature of learning needs to be emphasised. Human learning is not easy. In fact, my earlier argument suggested that the distinctive nature of human learning arose as a response to potential extinction. Biesta (2013) famously declared that education requires a "beautiful risk" to be taken, and yet the educators" focus on qualifications has begun to destroy any risky learning moments that may still remain in formal education settings. Learning and teaching require the ability to sit with uncertainty and to make artisan-like individual decisions, either as a novice or a professional (Bainbridge and West 2020).

The impact of league table reporting has led to a narrow focus on qualification and "game-playing". Educational institutions now devote considerable energy and resources to ensuring that the metrics required for league table positions are prioritised. In my own context of UK higher education, whole departments exist to manage Research Excellence Framework submissions, and a host of activities (and compromises?) are put in place to ensure that student academic and satisfaction scores are high. Academic writing is monitored to ensure that it has measurable "impact". Under the violent and fatalistic logic of capitalism, educational, social and environmental graves are being dug deeper and deeper, while governments and policymakers stand at the graveside cheering the zombie spectre of an education that never was (or will be) excellent.

The suffering caused by COVID-19 was never the intention of the contemporary formal education system, but the latter is nevertheless complicit in the former. Ever since our human ancestors first attempted to learn from and modify their external world, their actions have damaged a complex ecology. The neoliberal practices that now entrap education systems have led to conceptions of the world that promote capitalist assumptions of profit and accumulation, increasing metabolic rift. The violent magic trick of capital can be distilled into the moments when, despite knowing the inherent risks, the planet's resources continue to be plundered. Examples include felling ancient trees deep in a complex forest ecology, continually pouring herbicides, pesticides and insecticides on agricultural land, and valuing qualification and earnings above understanding and collaboration.

Having explored why the wicked problem exists, I now briefly turn my attention to how we might get out of this grave. Fortunately, the questions asked by Marx to

\footnotetext{
16 A unique selling point (USP) is a product's distinctive feature or characteristic which makes it different from competitors' products. The term is used in marketing to improve sales.

17 A golden bullet (or a silver bullet) is a somewhat improbable solution to a complex problem.
} 
emancipate the worker can also be used to reconnect the learner with an education that has the breadth and depth of human learning as its focus.

\section{Emancipation: a hopeful way forward}

Although almost 200 years old, Marx's insight into the workings of capital are still relevant, much more for the questions he asks than for any clear guidelines for future action. Marx's radicalism comes from the critical lens through which he viewed a rapidly changing world, asking questions and observing phenomena that others before him had failed to notice. In this article, I present both the global coronavirus pandemic and the stultification of formal education by neoliberal technologies through a Marxian lens as the result of profit-making mentalities and the capitalist conflation of use and exchange value.

As formal education is itself situated within a dialectic context, it is both the product and producer of human thinking. Education is not a static enterprise, and global responses to the coronavirus pandemic provide an opportunity to resist the dominance of neoliberal thinking in education, especially as there is much evidence to link global zoonotic pandemics to the activity of capital (Harvey 2020). It is therefore entirely reasonable to suggest that the global influence of neoliberal thinking on education is in no small way responsible for the widespread blindness to the negative outcomes of adaptive lag and metabolic rift.

Before considering how formal education may be changed by COVID-19 it is worth noting two broad but vital principles that Marx argued would lead to the emancipation of workers. In our context, emancipation will enable the educational labourer to control the process and outcomes of their learning. Marx's stance is dialectic and posits that any system change that can emancipate workers can only come about by changing all metabolic aspects of that system (i.e. technology, modes of production, relations to nature, social relations, mental conceptions and reproduction of everyday life). Mere tinkering around the edges will not bring about change. For example, technological change or an awareness of nature will not by themselves bring about emancipation (Marx 1996 [1887], p. 330). Of equal significance is Marx's insightful observation that individuals are "fettered", ${ }^{18}$ and that our full capabilities can only be realised in collaboration with others (ibid.). Marx's analysis is clear and has direct application to the world of modern formal education. PostCOVID-19 changes that have any chance of being significant and long-lasting must take into account the wider ecology (metabolism) of teaching and learning. Equally, it must be recognised that strategies to enhance individual learning are more likely to be successful when considered as part of a wider collective endeavour.

A successful approach to managing the spread of coronavirus requires each individual to consider their actions in relation to others, and a new approach to education must do the same. A suitable response might entail reducing the annual competitive

\footnotetext{
18 In Marxian terms, being fettered refers to how human abilities are actually restricted by technology and the competitive practices of capitalism.
} 
testing and reporting of student achievement throughout the years of compulsory education. Indeed, this once unimaginable change has already been brought about by COVID-19, with the cancellation of all 2020 formal school examinations in the UK. Wider changes to all aspects of metabolic relations will also be required if learning is to be saved from the death-like grasp of neoliberalism. Marx encourages resistance, and Biesta (2015) also sees it as the duty of education to resist. Despite their very different philosophical backgrounds, the recommendation is the same: if education is to fulfil its purpose to benefit the self, the other and the planet we live on, then teachers and learners must resist the dominant paradigm of narrow marketdriven discourse.

The return to a philosophy of education oriented around use value would be a return to a more human approach to learning: one that is no longer standardised, tested and reported in a competitive market context, but that has more in common with the ancient learning of the "artisan" situated in a natural world. The call here is not to return to an Edenic fantasy of humans and nature living together in harmony, but instead to consider what features of this learning experience can be applied in the current context. The discussion of metabolic rift suggests that the capitalist incursion into education has separated the learner and the process of learning. The "magic trick" ensures that this is hidden from awareness. I argue that what has been lost in this process is an understanding of human learning as something that cannot be entirely controlled by syntactic rules. Instead, learning is a semantic, ${ }^{19}$ meaningmaking exercise (Bainbridge 2019) which is complex and unpredictable, involving knowledge, anxiety, passion, spirit and bravery. These are not new ideas, but they are ones currently being strangled by a global educational monoculture. The factory inspectors reported by Marx knew this: they called for workers to be provided with educational opportunities that would allow them to become "fully developed human beings" (Marx 1996 [1887], p. 317). Education, they believed, should be open to serendipity ${ }^{20}$ and caprice and encourage tough and audacious (courageous) thinking. An education that is informed by metabolic relations or ecological sensibilities is not a "return to nature" per se, but it does take into account principles of connectedness and complexity, and enables individuals to make informed responses towards the self, the other and the planet we live on.

Humans have been digging their own grave, initially through open-world building which led to adaptive lag, deepened by the capitalist mindset and now immovably fixed in the structures of contemporary formal education. In an open world of adaptive lag and commodity fetishism, the human experience will always be insecure, and no product of human world-making will completely heal a continuing metabolic rift. The human experience is always changing and the future will continue to challenge us. It is the responsibility of those currently fortunate enough to have any influence to work collaboratively for the benefit of the self, the other and the planet

\footnotetext{
${ }^{19}$ In this context, syntactic refers to an understanding of learning that is based on rules and structures, whereas a semantic understanding of learning refers to how individual meaning is constructed. See Bainbridge (2021) for more details.

20 Serendipity refers to an accidental, fortunate turn of events, a stroke of luck.
} 
we live on. There will be other unavoidable pandemics, but the least we can do for future generations is to learn lessons from the current COVID-19 experience about the human relationship to nature and how capitalist epistemologies are hiding the use value of learning.

\section{References}

AoC (Association of Colleges) (2020). College key facts 2019/20 [leaflet]. London: Association of Colleges. Retrieved 12 June 2020, from https://www.aoc.co.uk/sites/default/files/AoC\%20College\%20 Key\%20Facts\%202019-20.pdf.

Bainbridge, A. (2014). Digital technology, human world making and the avoidance of learning. Journal of Learning Development in Higher Education. Special Edition: Digital technologies in Learning Development, Art. 2. Retrieved 12 June 2020, from https://journal.aldinhe.ac.uk/index.php/jldhe/ article/view/276.

Bainbridge, A. (2019). Education then and now: Making the case for ecol-agogy. Pedagogy, Culture \& Society, 27(3), 423-440. https://doi.org/10.1080/14681366.2018.1517130.

Bainbridge, A. (2021). Deceptively difficult education: A case for a lifetime of impact. In P. Howard, T. Saevi, A. Foran, \& G. J. J. Biesta (Eds.), Phenomenology and educational theory in conversation: Back to education itself (pp. 215-226). Abingdon: Routledge.

Bainbridge, A., \& Del Negro, G. (2020). An ecology of transformative learning: A shift from the ego to the eco. Journal of Transformative Education, 18(1), 41-58. https://doi.org/10.1177/1541344619 864670 .

Bainbridge, A., Gaitanidis, A., \& Chapman Hoult, E. (2018). When learning becomes a fetish: The pledge, turn and prestige of magic tricks. Pedagogy, Culture and Society, 26(3), 345-361. https:// doi.org/10.1080/14681366.2017.1403950.

Bainbridge, A., \& West, L. (2020). Narratives of fundamentalism, negative capability and the democratic imperative. In H. R. Wright \& M. Høyen (Eds.), Discourses we live by: Personal and professional narratives of educational and social practices (pp. 73-89). Cambridge, UK: Open Book Publishers.

Ball, S. J. (2018). Commericalising education: Profiting from reform! Journal of Education Policy, 33(5), 587-589. https://doi.org/10.1080/02680939.2018.1467599.

Berger, P. L. (1967). The sacred canopy: Elements of a sociological theory of religion. New York, NY: Anchor Books.

Berger, P. L., \& Luckmann, T. (1966). The social construction of reality: A treatise in the sociology of knowledge. London: Penguin.

Bhardwa, S. (2019). What is the TEF? Results of the teaching excellence framework 2019. Times Higher Education Student Blog, 19 June [blog post]. London: THE World Universities Insights Ltd. Retrieved 25 September 2020, from https://www.timeshighereducation.com/student/blogs/what-tefresults-teaching-excellence-framework-2019.

Biesta, G. J. J. (2013). The beautiful risk of education. Boulder, CO: Paradigm.

Biesta, G. J. J. (2015). The duty to resist: Redefining the basics for today's schools. Research on Steiner Education, 6 (special issue/ENASTE), 1-11. Retrieved 29 June 2020, from https://www.rosejourn. com/index.php/rose/article/view/265/260.

Biesta, G. J. J. (2019). Should teaching be re(dis)covered? Introduction to a symposium. Studies in Philosophy and Education, 38(5), 549-553. https://doi.org/10.1007/s11217-019-09667-y.

Burgess, S. (2020). How can we make up the learning losses from lockdown? [online article]. Economics Observatory (ECO). A collective initiative by the UK economic research community to answer questions about the economics of the Covid-19 crisis and the recovery. Retrieved 29 June 2020, from https://coronavirusandtheeconomy.com/how-can-we-make-learning-losses-lockdown.

Foster, J. B. (1999). Marx's theory of metabolic rift: Classical foundations for environmental sociology. American Journal of Sociology, 105(2), 366-405. https://doi.org/10.1086/210315.

Gamsu, S., \& Donnelly, M. (2020). Social network analysis methods and the geography of education: Regional divides and elite circuits in the school to university transition in the UK. Tijdschrift voor economische en sociale geografie [online first]. https://doi.org/10.1111/tesg.12413. 
Harvey, D. (2020). Anti-capitalist politics in the time of COVID-19. Jacobin, 20 March [online article]. Retrieved 12 June 2020, from https://jacobinmag.com/2020/03/david-harvey-coronavirus-politicaleconomy-disruptions.

Illich, I. (1971). Deschooling society. New York, NY: Harper and Row.

Jerrim, J. (2017). Extra time: Private tuition and out-of-school study, new international evidence. London: The Sutton Trust. Retrieved 15 June 2020, from https://www.suttontrust.com/wp-content/uploa ds/2017/09/Extra-time-report_FINAL.pdf.

Kendal, J. R. (2011). Cultural niche construction and human learning environments: Investigating sociocultural perspectives. Biological Theory, 6(3), 241-250. https://doi.org/10.1007/s1375 2-012-0038-2.

Laland, K. N., \& Brown, G. R. (2006). Niche construction, human behaviour, and the adaptive-lag hypothesis. Evolutionary Anthropology, 15(3), 95-104. https://doi.org/10.1002/evan.20093.

Lent, J. (2017). The patterning instinct: A Cultural history of humanities search for meaning. Amherst, New York: Prometheus Books.

Marx, K. (1996 [1887]). Capital: A critique of political economy, Volume. 1 (translated by. S. Moore \& E. Aveling; edited by F. Engels; transcribed 1995-1996 by Zodiac, H. Kuhls, A. Thurrott, B. McDorman, B. Schultz \& M. Gimenez). Moscow: Progress Publishers. Retrieved 12 June 2020, from https://www.marxists.org/archive/marx/works/download/pdf/Capital-Volume-I.pdf.

Morton, T. (2013). Hyperobjects: Philosophy and ecology after the end of the world. Minneapolis, MN: University of Minnesota Press.

Rowlandson, W. (2020). Living labs, mycelial networks and wild epistemologies. Reflections on emergent pedagogies in Higher Education in a time of crisis. Paper presented at the Sustainability in Higher Education Conference "The fierce urgency of now: Navigating paradoxes in sustainability education" (20-21 May 2020) at Canterbury Christ Church University, Canterbury, UK.

Tomasello, M. (2008). Origins of human communication. Cambridge, MA: MIT Press.

Vujaković, P. (2013). Phytobiography: An approach to "tree time" and "long-life learning". Arboricultural Journal, 35(3), 134-146. https://doi.org/10.1080/03071375.2013.852363.

Publisher's Note Springer Nature remains neutral with regard to jurisdictional claims in published maps and institutional affiliations.

Alan Bainbridge began working in Higher Education in 2001, having previously taught in secondary schools for 18 years. He is interested in the contested space between psychoanalytic thought and practices and education in its widest sense. He has written on how life history influences the development of educational professional practice and is currently using ideas linked to the Marxian and Freudian fetish to explore education processes. He is also interested in the interconnection between human learning and the "natural world". He is a co-coordinator of the European Society for Research on the Education of Adults (ESREA) Life History and Biography Network. 